\title{
Occupational risk factors and preventive measures for COVID-19 in prosthodontics
}

\author{
Tharuni Thammareddy1,, , Sujesh $\mathbf{M}^{2}$, Ravikumar $\mathrm{C}^{2}$, Srujana Zakkula ${ }^{3}$ \\ ${ }^{1}$ Postgraduate Student, ${ }^{2}$ Professor, ${ }^{3}$ Reader, Department of Prosthodonics, Mamata Dental College, \\ Giriprasad Nagar, Khammam, Telangana, India-507002.
}

\section{N F O R M A T I O N A B S T R A C T}

\section{Article History}

Received $1^{\text {st }}$ September 2020

Received revised $18^{\text {th }}$ November 2020

Accepted $1^{\text {st }}$ December 2020

Available online 29th December 2020

\section{K E Y W O R D S}

COVID-19

Infection control

Prosthodontic risk factors
Today, novel coronavirus infection has become pandemic worldwide. It is the primary cause of sickness from the common cold to severe acute respiratory syndrome in individuals. In a dental operatory, infections can be expedited through several routes like aerosol generation, contaminated surfaces, droplet splatter, oral fluids, and direct contact. Keeping in mind about the routes of transmission of COVID-19 (Coronavirus disease-19), dental practitioners are at higher risk of exposure and disease spread. Hence, this review article emphasizes the routes of transmission, risk factors, prophylactic and preventive measures. It also sights on alternative approaches to prosthodontic procedures to reduce the burden of COVID-19 infection in their community. Data acquisition was made using the keywords, COVID-19, infection control, prosthodontic risk factors in electronic databases like PubMed, Medline, ProQuest, etc. A manual search of several journals and books was also carried out, and only highly relevant articles were considered for the present review.

\section{Introduction}

The novel coronavirus (2019-nCoV) is rapidly spreading into public health crisis from its origin in Wuhan city of Hubei province of China, and its outbreak has gripped the whole world [1]. The World Health Organisation (WHO) on 11th February 2020, has declared a new name for the pandemic disease caused by 2019-nCoV as coronavirus disease (COVID-19). As for the virus alone, the International Committee on Virus Taxonomy has renamed the previously provisionally named 2019-CoV as Severe Acute Respiratory Syndrome Coronavirus-2 (SARS-CoV-2) [2,3]. They belong to a family of single-stranded RNA viruses known as Coronaviridae and are large in dimension varying from $60 \mathrm{~nm}$ to $140 \mathrm{~nm}[4]$.

These are primarily zoonotic, transmitting infection from animals to humans and humans to humans [5]. According to the China modelling study, the COVID-19 has a mean serial value of 5.8days between onset symptoms. The infectiousness has begun 2-3 days prior to the onset of symptoms and declined within seven days [6]. The transmission of SARS-CoV-2 has also been reported within the incubation period [7].

Dental care setups are always at high risk of COVID-19 infection. Its spread as

Correspondence: *Corresponding author Email Address: taruni.nancy@gmail.com

How to cite this article: Thammareddy T, Sujesh M, Ravikumar C, Zakkula S. Occupational risk factors and preventive measures for COVID-19 in prosthodontics. Int J Dent Mater 2020;2(4): 135-144. 
clinical procedures involves face to face communication with the patients and frequent exposure to saliva, blood, aerosols generation and oral cavity and respiratory system. The viable transmission of infection can be through the respiratory droplets, produced while coughing or sneezing, speaking as well as the spread can occur through contaminated surfaces (Figure-1).

So, the dental surgeons have to change protocols for protecting the patients, prevent the spread of COVID-19 and defend themselves by disinfecting and sterilizing dental operatory and postoperative disinfection and waste management [8].

\section{Clinical features (Table-1)}

Coronavirus causes sickness ranging from the common cold to more severe disease such as Middle East Respiratory Syndrome (MERS-CoV) and Severe Acute Respiratory Syndrome (SARS-CoV).

Risk factors: Aged people with additional medical co-morbidities like hypertension, diabetes mellitus, asthma, chronic obstructive pulmonary disease, and other cardiovascular conditions are more prone to develop a severe form of the disease [9].

\subsection{Preparation of operatory}

Dental surgery is a surgical procedure, and infection prevention has always been required for a healthy and effective dental practise $[10,11]$. Disinfection of dental operatory before and after treating the patients is required and numerous protocols including;

\subsubsection{Common ventilation for six minutes, air changes for each hour (ACH) of 60 minutes.}

\subsubsection{HEPA (High-efficiency particulate air) 13/14 air filters with minutes $12 \mathrm{ACH}$.}

\subsubsection{Disinfecting or defogging for 30-45 minutes:}

Ultraviolet germicidal irradiation (UVGI) plus two minutes to six hours of ventilation depending upon UV light position, wattage of the light source, and room size. UV-C disinfection is most effective against microbes and viruses in the present scenario.

\subsubsection{Fumigation:}

This method can be performed by electric boiler fumigation and potassium permanganate method. Formaldehyde, phosphine, 1,3-dichloropropane, hydrogen cyanide, chloropicrin, methyl isocyanate are the different agents used for Fumigation.

\subsubsection{Fogging}

Foggers generate a fog or mist formed by Ultra-low Volume (ULV) uniform sub-micron size liquid particles (Dry Fog) Glutaraldehyde, Glucoprotamine, Hydrogen Peroxide+ Silver Nitrate are different chemicals used for fogging procedure. Fogging is done using equipment called Fogger.

\subsubsection{Ultraviolet (UV) light:}

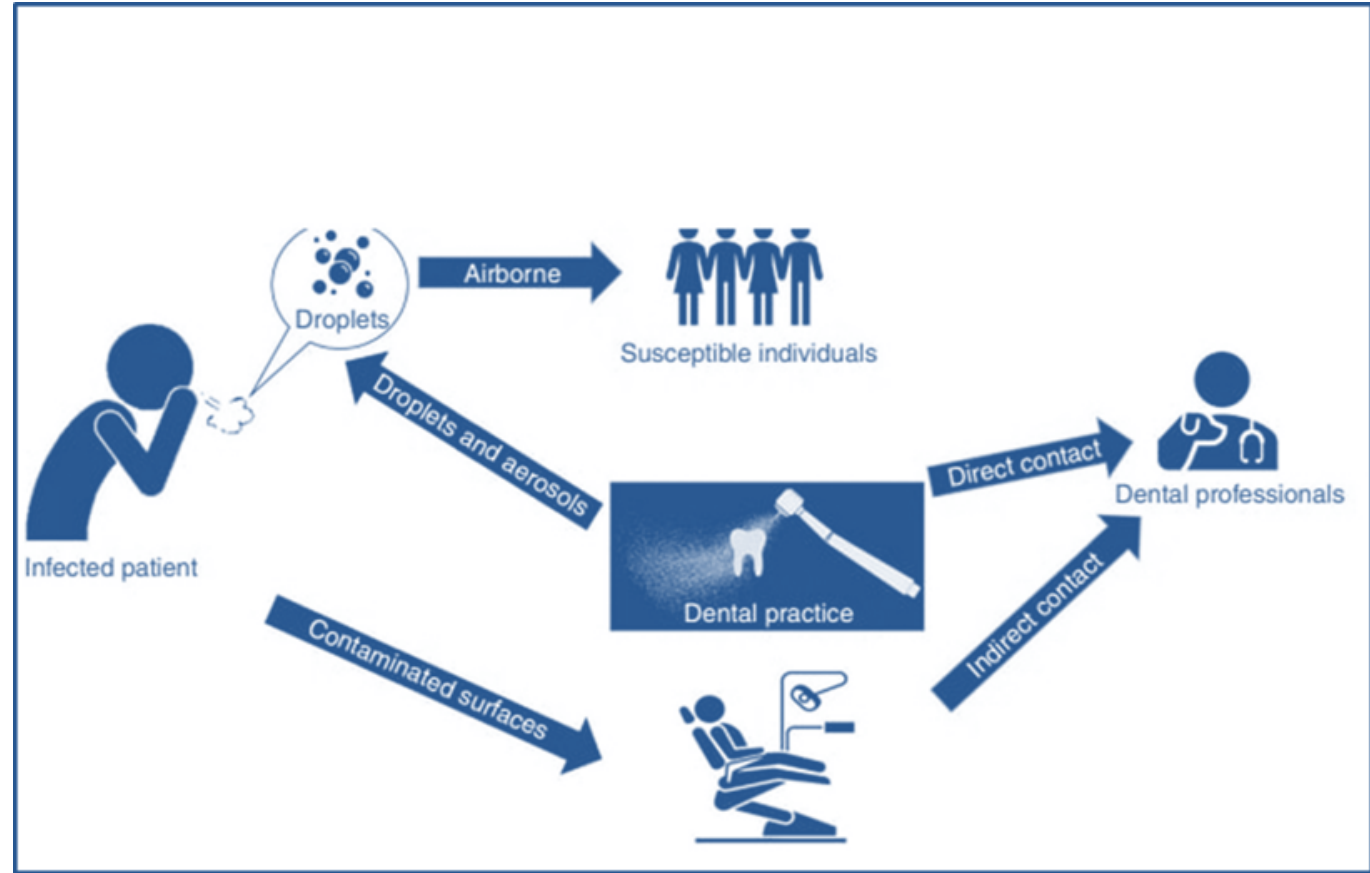


Table-1: Symptoms of COVID-19 [8]

Common symptoms

Fever

Cough

Fatigue

Shortness of breath
Less common symptoms

Myalgia/arthralgia

Headache

Sore throat

Chills
Rare symptoms

Nausea, vomiting

Nausea, congestion

Diarrhoea

Palpitations and chest tightness
Ultraviolet (UV) is the part of electromagnetic light constrained by the lower wavelength extreme of the visible spectrum and the $\mathrm{X}$-ray radiation band.

Using the Commission of Illumination classification, the UV spectrum is subdivided into three bands:

- UVA (long-wave) from 315 to $400 \mathrm{~nm}$

- UVB (medium-wave) from 280 to $315 \mathrm{~nm}$

- UVC (short-wave) from 100 to $280 \mathrm{~nm}$

UVC disinfection has attained more favour among these types because of its efficacy against a wide range of microbial and viral agents in various environments. The cellular RNA and DNA absorb high energy from the short-wavelength UVC light, damaging nucleic acids and preventing microorganisms from infecting and reproducing [12].

\subsubsection{Surface disinfection:}

Human coronavirus may live up to nine days at room temperature on an inert surface with a higher preference for humid circumstances. Sanitize inert surfaces using chemicals confirmed against COVID-19 and keep a dry atmosphere to reduce the increase of 2019-nCoV. Such surface sanitizers include 62-71\% ethanol, $0.5 \%$ hydrogen peroxide, and $0.1 \%(1 \mathrm{~g} / \mathrm{L})$ sodium hypochlorite.

\subsection{Sterilization of instruments}

All instruments are to be immersed in Sodium Hypchlorite+Detergent Solution 24 hours and then transferred to Ultrasonic cleaner the next day. Instruments must be wrapped in a sterilization pouch, and packaging should be done in a clean and low contamination area [13].

\subsection{Patient Evaluation}

The waiting room in the dental practice/center should be adequately ventilated. Prior to the patient's entry to the dental chair-side, patients should be provided with a surgical or face mask and disinfectant gel. The patient's temperature must be measured using a sterile or contact-free forehead thermometer. A pulse oximeter should be used for pre-screening to rule out reduced blood oxygen saturation levels, respectively. A detailed medical history should be taken from the patients, and a designated screening form must be precisely completed and signed by the patient (Figure-2).

If a patient is suspected to be positive, such patient should be immediately identified, quarantined and referred to the department of infection control in a hospital/center or the local health department.

In case of emergency dental complications, patients can undergo required treatments even if they are in the acute phase of the disease. According to WHO, the doubtful and healthy patients must be moved with negative pressure ventilation to precautionary rooms (12 air changes/hour "ACH" or $160 \mathrm{~L} / \mathrm{s} /$ patient).

Patients who do not report any symptoms can receive dental care and treatments [14].

\subsection{Rational use of Personal Protective Equipment (Ministry of Health \& Family Welfare)}

Personal Protective Equipment (PPEs) are protective gears designed to protect workers health by minimizing their exposure to a biological agent. (Figure-3).

\subsubsection{Sequence for Donning of components of PPE:}

First step: wear a head cap - Individuals using gowns, should use a headcover that covers the head and neck while providing clinical care for patients. Hair and hair extensions should fit inside the headcover.

Second step: Hand Hygiene - Hand hygiene is one of the principal pathways for reducing the transfer of microorganisms to the patients. According to WHO, SARS-CoV-2 can remain alive on different surfaces from the number of hours to several days. Since oral-faecal transmission of the virus has been reported for COVID-19, hand hygiene has become of the greatest importance for dental professionals/personnel. Hand hygiene can be achieved in two ways; handwashing with water and soap and hand disinfection using 


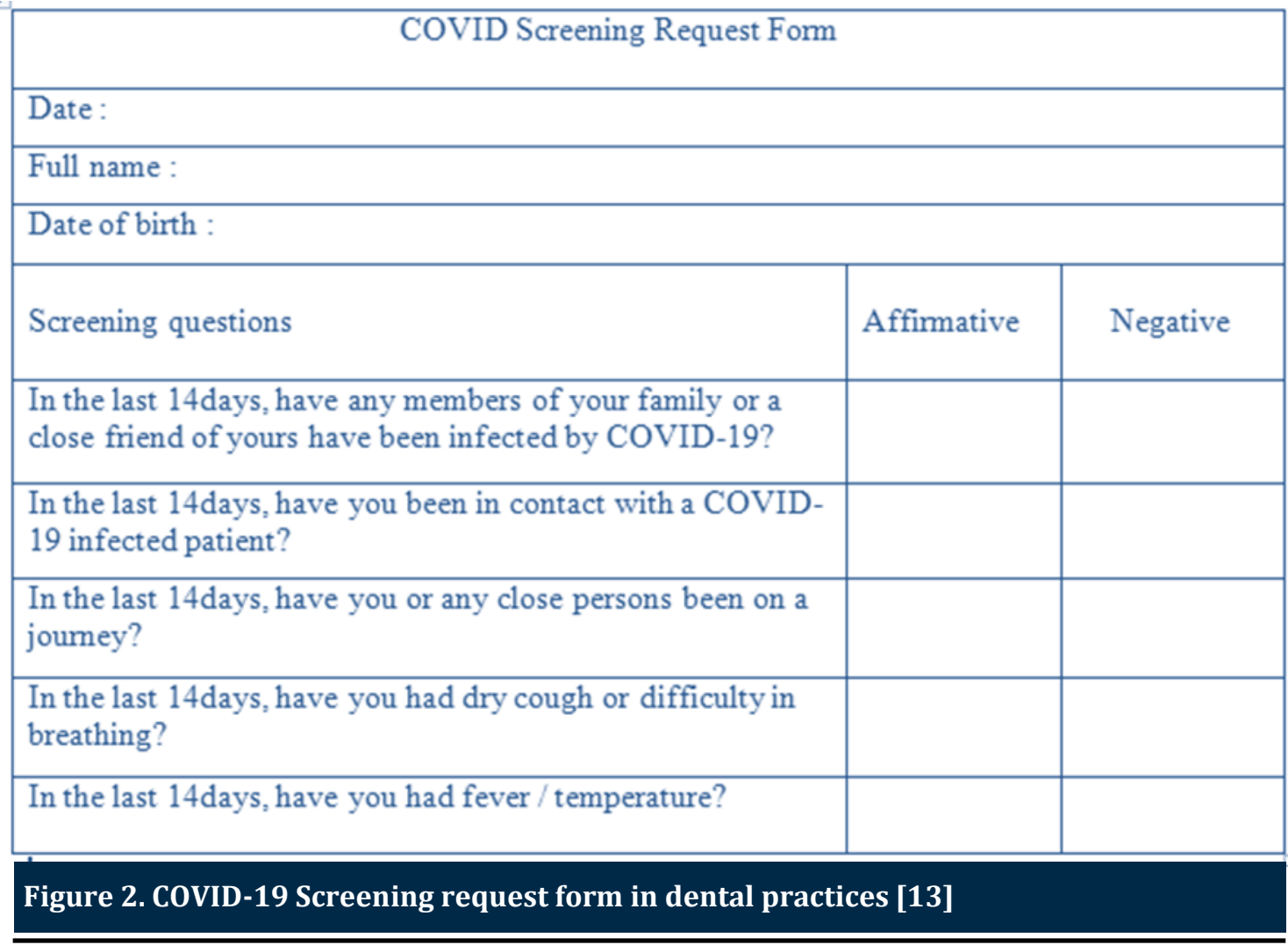

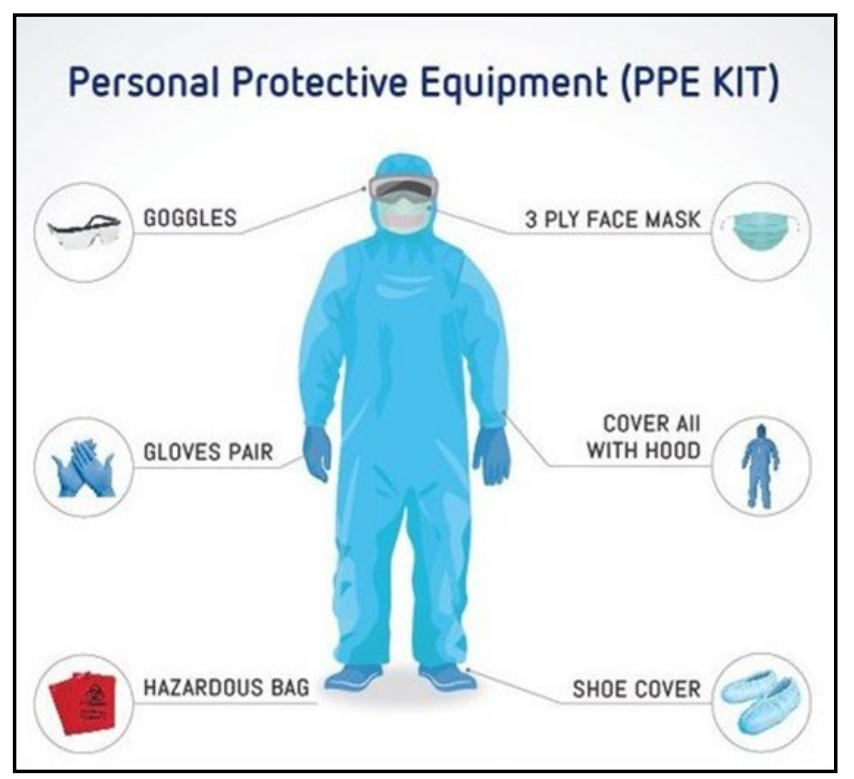

Figure-3 : Personal Protective Equipment

alcohol-based solutions, both for 20 seconds.

Third step: Put on Gown - Coverall/gowns are designed to protect the torso of healthcare providers from exposure to the virus. Coveralls typically provide 360 degree protection. Using suitable protective clothing makes it viable to create a barrier to eliminate or reduce contact and droplet exposure, both known to transmit COVID-19.

Shoe covers: Shoe covers have to be made up of impermeable fabric to be used overshoes to facilitate personal protection and decontamination.
Fourth step: Put on N-95/FFP2/FFP3 - Protecting the airway from the particulate matter generated by droplets. Commonly used surgical face masks in dentistry when correctly worn and frequently changed offers around 80\% filtration rate. COVID-19 measures around $120 \mathrm{~nm}(0.12 \mu \mathrm{m})$ and aerosol particle dimensions range from 3-100 $\mathrm{nm}$. The use of FFP3 respirator provides a filtration rate of $99 \%$ of all particles measuring up to $0.6 \mu \mathrm{m}$. An N-95 respirator mask is an airborne particle-protective respiratory system with high filtration capacity. To supply the requisite air seal to the wearer, such masks are designed to attain a very close facial fit.

Fifth step: Put on Goggles and Face shieldContamination of mucous membranes of the eyes, nose and mouth is more probable due to droplets generated by cough, sneeze of an infected person or during aerosol-generating procedures carried out in clinical situations. Hence it is important to protect them by using face shields/ goggles.

Sixth step: Put on Gloves - Nitrile gloves are preferred over latex gloves because they withstand chemicals, inclusive of certain disinfectants such as chlorine. There is an elevated rate of allergies to latex and contact allergic dermatitis among health workers. Non-powdered gloves are preferred to powdered gloves [15]. 
As patient needs, dentists should use their professional judgment to determine the emergency or urgent care. Urgent dental treatment is geared towards treating conditions that need urgent attention to relieve extreme pain and/or risk of infection and reduce the pressure on hospital emergency departments. These must be attended as minimally invasively as possible [16].

\subsection{Denture Repair}

In complete/partial denture cases, it is necessary to repair the fractured prosthesis to prevent mucosal irritation and trauma. Prosthetic devices can have an abundance of calculus and another tenacious bioburden. The debris should be removed to enable effective decontamination. To remove debris and contamination, the scrubbing should be done with a brush and antimicrobial soap. To remove the calculus, prostheses should be placed in sealable plastic bags or beakers filled with an ultrasonic purification solution. After this, the prostheses should be removed, rinsed under running tap water and dried before repairing the dentures. The denture is disinfected by immersing in $0.5 \%$ sodium hypochlorite for 10 minutes prior, which can otherwise lead to spread of infection.

\subsection{If permanent or temporary restorations are dislodged, re-cementation procedures are performed after pre-procedural mouth rinsing.}

A preoperative antimicrobial mouth rinse is generally thought to decrease the number of oral microbes. However, as set out in the Guideline for the Diagnosis and Treatment of Novel Coronavirus Pneumonia (5th edition) published by the People's Republic of China's National Health Commission, chlorhexidine, widely used as a mouth rinse in dental practice, may not be successful in killing 2019-nCoV. Since 2019-nCoV is vulnerable to oxidation, it is recommended to use preprocedural mouth rinse containing oxidative agents such as $1 \%$ hydrogen peroxide or $0.2 \%$ povidone to reduce the salivary load of oral microbes, including potential 2019-nCoV carriage [17].

Choose and modify trays to have the proper size for making the impression to prevent coughing. For extremely sensitive patients, the use of oral mucosa anaesthesia to the throat before making the impression is a good option [18]. Disinfection of impression trays prevents the spread of infection (Table-2).

\begin{tabular}{ll} 
Types of trays & Sterilization method \\
\hline Aluminium & $\begin{array}{l}\text { Heat sterilize via autoclave, chem- } \\
\text { ical vapor or dry heat; ethylene } \\
\text { oxide sterilization. }\end{array}$ \\
\hline Chrome-plated & $\begin{array}{l}\text { Heat sterilize via autoclave, chem- } \\
\text { ical vapor or dry heat; ethylene } \\
\text { oxide sterilization. }\end{array}$ \\
\hline Custom acrylic & $\begin{array}{l}\text { Discard after intraoral use in a } \\
\text { patient; disinfect with tuberculo- } \\
\text { cidal hospital disinfectant for re- } \\
\text { use during the same patient's } \\
\text { next visit. }\end{array}$ \\
\hline Plastic & Discard. \\
\hline
\end{tabular}

Impressions taken from the patient's mouth are also significant sources of contamination. If an impression is taken, it must be properly rinsed under tap water to eliminate saliva, blood, and debris, and then disinfected preceding to delivery to prosthodontic laboratories (Table 3). The disinfection procedure is as follows;

a. Initial irrigation using tap water.

b. Placement of material in disinfectant.

c. Re-irrigation using tap water [19].

Crown/bridge cementation can be done as urgent dental care. Preceding a fixed prosthesis's cementation, it is mandatory to disinfect to prevent the spread of infection (Table-4) [20].

If there is any necessity for handpiece usage, rubber dam isolation, and use of anti-retraction handpiece is advisory to prevent aerosols spread and crosscontamination.

Rubber dam isolation: The use of rubber dam can significantly minimize saliva production- and bloodcontaminated aerosol or spatter, especially in cases when high-speed handpieces and dental ultrasonic devices are used. It was outlined that the use of rubber dam could reduce airborne particles by $70 \%$ in the operating field's approximately 3 -foot diameter [21].

Anti-retraction handpiece: Without anti-retraction valves they may aspirate and expel the debris and fluids during the dental procedures. The high-speed dental anti-retraction handpiece can significantly reduce the backflow of oral bacteria and Hepatitis-B Virus (HBV) into the handpiece and dental unit tubes compared to the handpiece without any anti-retraction function. Anti-retraction dental handpiece with specially 


\section{Table 3. Levels and types of disinfection of impressions [18]}

\begin{tabular}{|c|c|c|c|c|c|}
\hline $\begin{array}{c}\text { Type of } \\
\text { disinfection }\end{array}$ & Disinfectant & $\begin{array}{l}\text { Recommended } \\
\text { concentration }\end{array}$ & $\begin{array}{c}\text { Type of } \\
\text { impression } \\
\text { material }\end{array}$ & $\begin{array}{l}\text { Time of } \\
\text { exposure }\end{array}$ & $\begin{array}{l}\text { Commercial } \\
\text { preparation }\end{array}$ \\
\hline $\begin{array}{l}\text { High level } \\
\text { disinfection }\end{array}$ & Glutaraldehyde & $2 \%$ & $\begin{array}{l}\text { Irreversible } \\
\text { hydrocolloid } \\
\text { Zinc oxide } \\
\text { eugenol } \\
\text { Poysulfide } \\
\text { Polyether } \\
\text { Addition } \\
\text { silicone }\end{array}$ & $\begin{array}{l}10 \mathrm{~min} \\
10 \mathrm{~min} \\
10 \mathrm{~min} \\
10 \mathrm{~min}\end{array}$ & Cidex \\
\hline \multirow{5}{*}{$\begin{array}{l}\text { Intermediate } \\
\text { level } \\
\text { disinfection }\end{array}$} & $\begin{array}{l}\text { Sodium hypo- } \\
\text { chlorite }\end{array}$ & $\begin{array}{c}0.5 \% \\
\text { Or } \\
200-5000 \text { PPM }\end{array}$ & $\begin{array}{l}\text { Impression } \\
\text { compound. }\end{array}$ & $10 \mathrm{~min}$ & $\begin{array}{l}\text { Purex } \\
\text { Clorox } \\
\text { Chloramine T }\end{array}$ \\
\hline & Iodophores & $1-2 \%$ & $\begin{array}{l}\text { Irreversible } \\
\text { hydrocolloid, } \\
\text { Zinc oxide }\end{array}$ & $10 \mathrm{~min}$ & \multirow{4}{*}{$\begin{array}{l}\text { Betadine } \\
\text { Hy-sine } \\
\text { Ioprep } \\
\text { Lysol } \\
\text { Dettol } \\
\text { Hi-phene } \\
\text { Isopropyl alco- } \\
\text { hol } \\
\text { Savlon }\end{array}$} \\
\hline & Phenols & $1-3 \%$ & $\begin{array}{l}\text { Eugenol. } \\
\text { Polysulfide' } \\
\text { Polyether, }\end{array}$ & $10 \mathrm{~min}$ & \\
\hline & Alcohols & $60-90 \%$ & $\begin{array}{l}\text { Addition } \\
\text { silicone }\end{array}$ & $10 \mathrm{~min}$ & \\
\hline & Chlorhexidine & $2-4 \%$ & & $10 \mathrm{~min}$ & \\
\hline $\begin{array}{l}\text { Low level disin- } \\
\text { fection }\end{array}$ & $\begin{array}{l}\text { Quaternary ammo- } \\
\text { nium compounds } \\
\text { Simple phenol } \\
\text { detergents }\end{array}$ & Not recommendec & or impression c & ection & \\
\hline
\end{tabular}

\section{Table 4. Disinfection of prosthesis, casts, wax rims, jaw relation records [19]}

Stone casts

Fixed (metal/porcelain)

Wax rims or bites

specially designed anti-retractive valves or other antireflux designs is highly recommended for crossinfection as an extra preventive measure [22].

A high-volume evacuator (HVE) is a suction device that pulls a large amount of air over some time and is mounted into an evacuation system that is said to expel up to 100 cubic feet of air per minute. HVE can reduce aerosols, but clinicians should consider certain technical requirements when using HVE [23].

Sterilization and disinfection of dental instruments, materials and commonly used items prior to treatment procedure is mandatory (Table-5).
Spray or immerse in hypochlorite or iodophor

Immerse in gutaraldehyde

Spray-wipe-spray with iodophors

Urgent treatment procedures, aerosol-generating procedures (AGP) and non-aerosol generating procedures (NGP) will have to be managed in current situations. Urgent AGP includes preparation of abutment in previously placed implants where it is not recommended to delay prosthetic rehabilitation, Occlusal modification of a cement or screw-retained implant prosthesis where the interferences result in discomfort and/or inflammation.

Screw-retained prosthesis: Inspection of the access hole in case of loosening of the screw, Full mouth rehabilitation of a debilitated patient wherein functional rehabilitation is unachievable with a removable prosthesis. 
Table 5. Sterilization and disinfection of dental instruments, materials, $\&$ few commonly used items [17]

\begin{tabular}{|c|c|c|c|c|c|c|c|}
\hline & & $\begin{array}{c}\text { Steam } \\
\text { Autoclave }\end{array}$ & $\begin{array}{c}\text { Dry } \\
\text { Heat } \\
\text { Oven }\end{array}$ & $\begin{array}{l}\text { Chemical } \\
\text { Vapor }\end{array}$ & $\begin{array}{l}\text { Ethylene } \\
\text { Oxide }\end{array}$ & $\begin{array}{l}\text { Chemical } \\
\text { Agents }\end{array}$ & $\begin{array}{l}\text { Other Methods } \\
\text { \& Comments }\end{array}$ \\
\hline \multirow{3}{*}{ Burs } & Carbon & - & ++ & ++ & ++ & - & Discard \\
\hline & Steel & + & ++ & ++ & ++ & - & Discard \\
\hline & $\begin{array}{l}\text { Tungston- } \\
\text { carbide }\end{array}$ & + & ++ & ++ & + & - & Discard \\
\hline \multicolumn{2}{|l|}{ Dapen dishes } & ++ & + & + & ++ & + & \\
\hline \multicolumn{2}{|l|}{ Glass slabs } & ++ & ++ & ++ & ++ & + & \\
\hline \multicolumn{2}{|l|}{ Handpieces* } & $(++)^{*}$ & - & $(+)^{*}$ & ++ & & \\
\hline \multicolumn{2}{|l|}{ Contra-angles } & ++ & - & ++ & ++ & & \\
\hline \multirow{3}{*}{$\begin{array}{l}\text { Polishing } \\
\text { wheels \& } \\
\text { disks }\end{array}$} & $\begin{array}{l}\text { Garnet and } \\
\text { cuttle }\end{array}$ & $=$ & - & - & ++ & $=$ & \\
\hline & Rag & ++ & - & + & ++ & $=$ & \\
\hline & Rubber & + & - & - & ++ & - & \\
\hline \multicolumn{2}{|c|}{ Protheses, removable } & - & - & - & + & + & \\
\hline \multirow{3}{*}{$\begin{array}{l}\text { Rubber dam } \\
\text { equipment }\end{array}$} & $\begin{array}{l}\text { Carbon steel } \\
\text { clamps }\end{array}$ & - & ++ & ++ & ++ & - & \\
\hline & $\begin{array}{l}\text { Metal } \\
\text { frames }\end{array}$ & ++ & ++ & ++ & ++ & + & \\
\hline & $\begin{array}{l}\text { Plastic } \\
\text { frames }\end{array}$ & - & - & - & ++ & + & \\
\hline \multicolumn{2}{|l|}{ Punches } & - & ++ & ++ & ++ & + & \\
\hline \multicolumn{2}{|c|}{ Stainless steel clamps } & ++ & ++ & ++ & ++ & + & \\
\hline \multicolumn{2}{|c|}{$\begin{array}{l}\text { Saliva evacuators, ejectors } \\
\text { (plastic) }\end{array}$} & - & - & - & - & & $\begin{array}{c}\text { Discard }(++) \\
\text { (single use / dis- } \\
\text { posable) }\end{array}$ \\
\hline \multirow{3}{*}{ Stones } & Diamond & + & ++ & ++ & ++ & + & \\
\hline & Polishing & ++ & + & ++ & ++ & - & \\
\hline & Sharpening & ++ & ++ & ++ & - & - & \\
\hline \multicolumn{2}{|c|}{$\begin{array}{l}\text { Surgical instruments Stain- } \\
\text { less steel }\end{array}$} & ++ & ++ & ++ & ++ & - & \\
\hline \multicolumn{2}{|c|}{ Water-air syringe tips } & ++ & ++ & ++ & ++ & - & Discard (++) \\
\hline
\end{tabular}

++ Effective and preferred method.

+ Effective and acceptable method.

- Effective method, but risk of damage to materials.

$=$ Ineffective method with risk of damage to materials.

* Since manufacturers use a variety of alloys and materials in these products, confirmation with the equipment manufacturers is recommended, especially for handpiece's and their attachments. 
In a case of full mouth rehabilitation, welding is required to repair a broken superstructure, Rehabilitation of an anterior region that affects the quality of life and hindering the day to day functions like speech, mastication etc.

NGP includes the following;

- Placement of prosthesis on already prepared abutments.

- Repair of the broken dentures/ prosthesis supported by implants in geriatric/ debilitated patients/ in patients affecting the function and quality of life.

- Tightening of loose overdenture attachments making the denture unstable or difficult to seat/ tightening of loose screws in a screw-retained prosthesis.

- Repair of a broken occlusal splint in cases of full mouth rehabilitation with high muscular forces.

- Re-cementation of a dislodged implant-supported cement-retained prosthesis, placement of gingival formers of previously placed implants, wherein delay in prosthetic rehabilitation can hinder functional day-to-day activities like mastication.

\subsection{Modifications for implant-related procedures}

Various alterations/ additions can ensure safety and increased success for implant placement's surgical procedure. Wherever possible, Hand instruments to be preferred over rotary instruments. Using surgical guides / full-guided surgery techniques will reduce radiological exposure and improve the precision to prevent failure and complication [24]. Implant placement procedures can be done at a low torque value (approximately $300 \mathrm{rpm}$ ) following the initial drill to decrease the aerosol generation. Using aggressive thread implants/ implant system with fewer sequential drilling systems can minimize the aerosols generated.

Gingival former should be placed at the time of surgery wherever indicated, and resorbable membranes should be encouraged to avoid a second surgical exposure reducing the number of appointments. Patients can be instructed to follow a post-procedural mouth rinse with a mouthwash containing active oxygen along with oral irrigation devices to promote healing and avoid difficulties such as peri-implantitis. Nylon and Polytetrafluoroethylene sutures can be preferred as they can be used for more extended periods and save a suture removal appointment [25].
Immediate loading should be preferred wherever indicated to minimize the number of appointments. One abutment-One-time concept can eliminate all the dis/reconnections taking place during the course of treatment and allows for immediate provisionalisation, thus reducing overall treatment time. A Screwretained Prosthesis should be preferred in every case, as a provisional as well as a permanent restoration [26].

Angulated Screw Channel (ASC)/ Customized abutments facilitate a screw-retained restoration for any given circumstances. During provisionalisation with a screw-retained provisional restoration, filling the access hole with PTFE tape can be encouraged, avoiding composite or cement on top, thus preventing aerosol generation during removal. If any modifications have to be made in the prosthesis, it should be done outside the mouth using a low-speed rotary handpiece in an enclosed transparent chamber with a provision for suctioning minimizing the fragments generated [27].

\section{Biomedical waste management}

After use, the medical waste that contains disposable protective equipment should be delivered promptly to the medical center's temporary storage facility. The reusable tools and materials should be cleansed, sterilized, and carefully preserved in consent with the Protocol for the Disinfection and Sterilization of Dental Instruments. Medical and domestic waste generated by treating suspected or confirmed cases of COVID-19 is considered a medical infectious waste. Double-layer, yellow clinical waste bags should be used with a "gooseneck" knot. The surface area of the waste bags should be labelled and disposed of according to medical waste disposal requirements. All the biohazardous waste should be disposed of by government guidelines [28].

\section{Prophylactic care}

The National Task Force for COVID19 constituted by Indian Council of Medical Research recommended hydroxychloroquine for treatment of COVID-19 for high-risk cases. Asymptomatic health care workers involved in the care of suspected or confirmed cases of COVID-19: 400mg twice a day on day1, followed by $400 \mathrm{mg}$ once weekly for next 7 weeks to be taken with meals. 


\subsection{Contraindications}

The drug is not recommended for prophylaxis of children under 15 years of age.

In persons with a known case of retinopathy, known hypertensive to hydroxychloroquine, 4-aminoquinoline compounds [29].

Hydroxychloroquine therapy is closely associated with reduced viral load/disappearance in patients with covid-19, and its effect is verified by azithromycin However, the drug system is not FDA approved, and work is still ongoing [30].

\section{Conclusion}

As COVID-19 has altered the lifestyle all over the globe. Considering the routes of COVID-19 transmission, even we as dental professionals have to alter and follow standard protocols for preventing the spread of infection. Dentists must have thorough knowledge about the signs and symptoms and follow strict infection control measures in such clinical situations. Without the potential to prevent community infection, prevention of health care transmission will remain a challenge.

Conflict of interests: Authors declared no conflicts of interest.

\section{Financial support: None}

\section{References}

1. Wang C, Harby PW, Hayden FG, Gao GF. A novel coronavirus outbreak of global health concern. Lancet. Elsevier public health emergency collection 2020;395:470-473. https://doi.org/10.1016/S0140-6736(20)30185-9

2. Brahmanandam PS, Chakravarthy KK, Raju GR, Rao NS, Satyavani M, Kumar VN, Alla RK, Kadiyala KG, Vinay $\mathrm{P}$, Rao C, Narsaiah EL. Feasible Solutions and Role of Nanomaterials in Combating the COVID-19 Pandemic: A Preliminary Study. Trends Biomater Artif Organs. 2020 Jul 3;34.

3. Gorbalenya AE, Baker SC, Barie RS, de Groot RJ, Drosten C, Gulyaeva AA, et al. Severe acute respiratory syndrome-related coronavirus: the species and its viruses-a statement of the Coronavirus Study Group. Bio Rxiv 2020: 1-15. https://doi.org/10.1101/2020.02.07.937862

4. Singhal T. A review of coronavirus disease-2019 (COVID-19). Ind J Pediatr. 2020;13:1-6. https:// doi.org/10.1007/s12098-020-03263-6

5. Wahba L, Jain N, Fire AZ, Shoura MJ, Artiles KL,
McCoy MJ, Jeong DE. Identification of a pangolin niche for a 2019-nCoV-like coronavirus through an extensive meta-metagenomic search. BioRxiv. 2020 Jan 1. https://doi.org/10.1101/2020.02.08.939660

6. He X, Lau EH, Wu P, Deng X, Wang J, Hao X, Lau YC, Wong JY, Guan Y, Tan X, Mo X. Temporal dynamics in viral shedding and transmissibility of COVID-19. Nat Med. 2020;26(5):672-5. https:// doi.org/10.1038/s41591-020-0869-5

7. Wei WE, Li Z, Chiew CJ, Yong SE, Toh MP, Lee VJ. Presymptomatic Transmission of SARS-CoV-2Singapore, January 23-March 16, 2020. Morbidity and Mortality Weekly Report. 2020;69(14):411. https://doi.org/10.15585/mmwr.mm6914e1

8. ISOI Guidelines for Dental Practitioners During COVID-19 Pandemic.

9. Guan WJ, Ni ZY, Hu Y, Liang WH, Ou CQ, He JX, Liu L, Shan H, Lei CL, Hui DS, Du B. Clinical characteristics of coronavirus disease 2019 in China. N Engl J Med. 2020;382(18):1708-20. https:// doi.org/10.1056/NEJMoa2002032

10. Biradar SV. Sterilization in Dental Practice-A Review. Asian J Pharm Technol Innov. 2018;6(27): 5366.

11. Chidambaranathan AS, Balasubramanium M. Comprehensive review and comparison of the disinfection techniques currently available in the literature. J Prosthodont. 2019;28(2):e849-56.

https://doi.org/10.1111/jopr.12597

12. Dr Ajay Bajaj, How to use Ultraviolet light (UVC) to fight COVID-19 effectively in dental clinics. https:// in.dental-tribune.com/news/how-to-use-ultravioletlight-uvc-to-fight-covid-19-effectively-in-dentalclinics-dr-ajay-bajaj/ Accessed on 14th August 2020.

13. Fini MB. What dentists need to know about COVID19. Oral Oncology. 2020 Apr 28:104741. https:// doi.org/10.1016/j.oraloncology.2020.104741

14. Shamszadeh S, Parhizkar A, Mardani M, Asgary S. Dental Considerations After the Outbreak of 2019 Novel Coronavirus Disease: A Review of Literature. Arch Clin Infect Dis. 2020;15(2): e103257. https:// doi.org/10.5812/archcid.103257

15. World Health Organization. Rational use of personal protective equipment for coronavirus disease (COVID-19) and considerations during severe shortages: interim guidance, 6 April 2020. World Health Organization; 2020.

16. ADA Website Guidance on Emergency vs Non Emergency. April 7, 2020.

17. Ahmed MS, Barman D, Girish B, Devi RE, Kazi S, Bhure S, Tiwari RV. Dental considerations in Corona Virus Infections: First review in literature. J Adv Med Dent Sci Res. 2020;8(2):100-3.

18. Affairs AC, Practice AC. Infection control recommendations for the dental office and the dental laboratory. J Am Dent Assoc. 1996;127(5):672-80. https:// doi.org/10.14219/jada.archive.1996.0280 
19. Khan MW. An Overview of Dental Impression Disinfection Techniques-A Literature Review. JPDA. 2018;27(04):208. https://doi.org/10.25301/JPDA.274.207

20. Bhat VS, Shetty MS, Shenoy KK. Infection control in the prosthodontic laboratory. J Ind Prosthodont Soc. 2007;7(2):62. https://doi.org/10.4103/0972-4052.33997

21. Samaranayake LP, Reid J, Evans D. The efficacy of rubber dam isolation in reducing atmospheric bacterial contamination. ASDC J Dent Child. 1989;56 (6):442-4.

22. Peng $\mathrm{X}, \mathrm{Xu} \mathrm{X}$, Li Y, Cheng L, Zhou X, Ren B. Transmission routes of 2019-nCoV and controls in dental practice. Int J Oral Sci. 2020;12(1):1-6. https:// doi.org/10.1038/s41368-020-0075-9

23. Avasth A. High Volume Evacuator HVE in reducing aerosol an exploration worth by clinicians. J Dent Health Oral Disord Ther. 2018;9(3):165-6. https:// doi.org/10.15406/jdhodt.2018.09.00371

24. Colombo M, Mangano C, Mijiritsky E, Krebs M, Hauschild U, Fortin T. Clinical applications and effectiveness of guided implant surgery: a critical review based on randomized controlled trials. BMC Oral Health. 2017;17(1):150. https://doi.org/10.1186/s12903-017-0441-y

25. Rashed HT. Evaluation of the effect of hydrogen peroxide as a mouthwash in comparison with chlorhexidine in chronic periodontitis patients: a clinical study. J Int Soc Prev Community Dent. 2016;6 (3):206-212. https://doi.org/10.4103/2231-0762.183114

26. Atieh MA, Tawse-Smith A, Alsabeeha NH, Ma S, Duncan WJ. The One Abutment-One Time Protocol: A Systematic Review and Meta-Analysis. J Periodontol. 2017;88(11):1173-85. ㄴtps:// doi.org/10.1902/jop.2017.170238

27. Sakamoto S, Ro M, Al-Ardah A, Goodacre C. Esthetic abutment design for angulated screw channels: A technical report. J Prosthet Dent. 2018;119(6):9125. https://doi.org/10.1016/j.prosdent.2017.08.018

28. Hegde V, Kulkarni RD, Ajantha GS. Biomedical waste management. J Oral Maxillofac Pathol. 2007;11(1):5-9.

https://doi.org/10.4103/0973-029X.33955

29. National Task Force for Covid 19. Advisory on the use of Hydroxychloroquine as prophylaxis for SARS -CoV-2 infection. New Delhi: ICMR; 2020 March 22.

30. Gautret P, Lagier JC, Parola P, Meddeb L, Mailhe M, Doudier B, Courjon J, Giordanengo V, Vieira VE, Dupont HT, Honoré S. Hydroxychloroquine and azithromycin as a treatment of COVID-19: results of an open-label non-randomized clinical trial. Int $\mathrm{J}$ Antimicrob Agents. 2020 Mar 20:105949. https:// doi.org/10.1016/j.ijantimicag.2020.105949 